\title{
CONSUMPTION TAXATION AS AN INSTRUMENT OF ECONOMIC CONTROL
}

\author{
Albert Gailord Hart*
}

The proposition that taxation can and should be planned largely with a view to regulating economic activity is accepted, contrary to a sedulously cultivated popular tradition, by most economists of all schools. In view of the high percentage of national income absorbed by taxation, the types of taxes levied and the rates fixed cannot fail to influence profoundly the size and composition of our national output, and the way in which that output is shared. In consequence there is no issue as to whether taxation is to be allowed to have regulatory effects. The issue is only whether these effects shall be recognized, measured, and taken explicitly into account as a major element in framing tax policy, or whether they shall be publicly ignored and left to take the form of "riders" on measures ostensibly framed purely for revenue.

The principal regulatory effects, intentional or unintentional, of consumption taxes $^{1}$ may be classified roughly as follows:

(I) Effects on the relative consumption volume and prices of different sorts of goods.

(2) Effects on the general direction of change of consumption volume and prices.

(3) Effects on the distribution of the fruits of economic activity among persons and groups.

On the nature and extent of these effects, economists of all schools should be able to approach agreement; though the approach cannot be very close, since there is

- A.B., r930, Harvard University; Ph.D., 1936, University of Chicago. Associate Professor of Economics, Iowa State College. Previously Instructor in Economics, University of Chicago; Economic Analyst, United States Treasury; Director of Research, Committee on Debt Adjustment, Twentieth Century Fund. Author, Debts and Recoverx (1938); Anticipations, Uncertainty and Economic Planning (1940); co-author of work on defense financing now in press.

${ }^{1}$ By consumption taxes the writer means taxes proportioned either to the physical volume of some type of goods or services passing to consumers for household use or else to consumers' money outlay on such a type of goods or services. In addition to excise taxes and sales taxes, levied on sellers to consumers, this definition may be taken to include taxes levied on consumers directly (which for administrative reasons we do not have), either on particular purchases or on total spendings. Income taxes are clearly excluded by this definition; taxes on goods destined for consumers at the wholesale or manufacturing levels, being approximately proportioned to consumption volume, lie close outside the boundary the definition draws, and are covered by most of the analysis of this paper even where not cxplicitly mentioned. Cf. Studenski, Characteristics, Developments and Present Status of Consumption Taxes, supra this issue. 
room for honest differences about various relevant questions of fact, and since it seems to be impossible to spell out the analytical procedure in enough detail absolutely to rule out illicit logical jumps.

It is harder to set forth a generally acceptable list of regulatory goals for consumption taxes. But the writer proposes the following:

(A) Justice in distributional effects. More concretely, this means in most contexts a tendency to reduce rather than increase the inequality of income distribution; though the writer can think of special cases where he feels just treatment would increase inequality.

(B) A high level of employment and production.

(C) Charging to particular producers and consumers special benefits obtained from government.

(D) Charging to particular producers and consumers costs which their operations impose upon others and which the market mechanism does not bring home to them. ${ }^{2}$

(E) Representation of social interests in greater or less use of particular articles, even though these interests cannot be accurately valued in money-for example, the public interest in reducing whisky consumption, protecting health by stimulating use of vitaminrich foods, or diverting aluminum from kitchen uses to defense. This is very close in principle to goal (D), as is also goal (C).

While goals (C), (D) and (E) can on the whole be reconciled, real conflicts exist in some cases among goals (A), (B) and (C) and the principles of a desirable compromise solution are difficult to state.

\section{II}

In view of growing professional and public interest in the monetary effects of public finance, the body of this paper will be opened by considering possibilities of using consumption taxes as an auxiliary in a general program of stabilizing employment and production at satisfactorily high levels.

Consumption taxes immediately payable by sellers (as all actual consumption taxes are) drive a wedge between the price of consumer goods as paid by the consumer and the price as realized (net of tax), by the seller. Accordingly, the effect of such taxes in themselves-that is, assuming government expenditures and other tax rates would be the same whether or not these taxes were levied-is to discourage production of consumer goods. ${ }^{3}$ For if prices to consumers rise, a given

\footnotetext{
${ }^{2}$ For example, operations at one oil well increase the amount of pumping necessary to raise oil at other wells in the same field; and if opening the well will not repay enough above its costs to cover the extra costs imposed on other wells, it is not socially desirable. If each well had to meet a tax representing these extra costs, opening of superfluous wells would be discouraged. Note that this presumption does not apply if the extra costs imposed elsewhere result merely from higher prices of labor equipment or materials rather than from impairment of technical efficiency. As the chicf authors of this line of reasoning, Alfred Marshall and A. C. Pigou, have pointed out, it also indicates a claim to subsidy where operations produce benefits for which the producers are not able to collect-for instance where electrification of a suburban railway would improve living conditions in the neighborhood. This is not surprising since a subsidy or bounty is mercly a tax with a minus sign. Most of the arguments of this paper relating to taxes apply, with sign reversed, to bounties as well.

${ }^{3}$ For an interesting discussion of the strongly analogous problem of payroll taxes sec Kaldor, Wage Subsidies as Remedy for Unemployment (1936) 44 J. Por. Econ. 721.
} 
amount of consumers' money outlay will buy fewer goods. But if prices to consumers do not rise, the prices realized by sellers will fall by the amount of tax, reducing incentives to produce. Prices to consumers can remain unchanged only if producers get costs reduced sufficiently to offset the tax; but this implies reducing wage rates and farm prices and thus reducing spending power, so that even at unchanged prices consumers can buy less.

Where proceeds of consumption taxes are applied to government spending which would otherwise be impossible, or to reduction of other taxes, this adverse effect on production will be attenuated, or in the most favorable case cancelled. If a by-product of the tax is to pour into consumption markets exactly as much money as the taxes drain off, net proceeds of sellers after taxes will be unaffected. The price paid by consumers will be increased, reducing the amount of goods the previous consumers can buy; but the people who get the extra funds will be able to buy more goods. In practice, however, a complete offset cannot be expected. Even in the most favorable case, that where the consumption taxes in question are levied by state or local governments which insist on balancing their budgets, not all the proceeds of the tax will take the form of consumer spending. If the proceeds go to additional salaries (even to additional relief payments), part will be saved by the recipients; and even more will be saved if the proceeds go to reduce income taxes or property taxes. ${ }^{4}$ Some adverse effect on consumer goods output must thus be expected; a minimum if proceeds all go to relief payments which would otherwise be impossible, a maximum if proceeds are net, other taxes and government expenditures being undisturbed, as is likely if federal taxes are being considered.

It follows from this argument that consumption taxes can play a useful role in economic stabilization if (and only if) the stabilization program calls for reducing the incentives to produce consumer goods. It is generally agreed that there is no use discouraging consumer goods production in the trough of the business curve; the issue in regard to consumption taxes is, therefore, whether they can usefully be levied in peak years.

At first glance, it is tempting to argue that the way to smooth the fluctuating curve of production and employment must be to level off the summits and fill in the valleys. Admitting that it would be better to raise the valleys without lowering the summits, stabilization at some sort of average level might have advantages over allowance of wild fuctuations. But it is by no means clear that flattening the peaks would raise the valleys. Even where full prosperity has not been attained, very sweeping business declines are possible; witness the United States in I937-1938 and Austria in r929-1932, both starting from depression levels. To propose discouraging consumption output at the peak is clearly dangerous.

In one rather important case, there is merit in reducing incentives for production. That is in the case where physical barriers make these incentives ineffective and

\footnotetext{
* For indication of the purposes to which consumption tax revenues are put, see Smart and Hart, The Distribution of Reventes from State-Collected Consumer Taxes, infra this issue.
} 
create a danger of their running off into needless increases of prices and profits. Where a rise in consumers' outlay cannot bring about a rise in output of consumer goods, tax diversion of outlays is in order to avoid inflation. This is likely to be the case in every wartime boom, and may sometimes be the case in peacetime.

'To admit a possible use for taxes to constrict consumers' money outlay, however, is not yet to justify use of consumption taxes for the purpose. Such taxes as we know them have the very great demerit of being regressive, in conflict with goal (A). A set of excise taxes or sales taxes designed to avoid this demerit would have to be confined to goods on which the rich spend a larger percentage of their income than do the poor, which would very sharply limit the tax base. The monetary purpose in view could be served without conflict with goal (A) by levying direct taxes on individuals with exemptions for minimum needs, and with progressive rates. Conceivably these taxes might be on consumption outlays as such (a new form of consumption tax); but both equity and administrative convenience suggest use of the income tax. Consumption taxes could be justified for this purpose only if income taxes were unavailable and the inequities of inflation were considered worse than those of levying the consumption taxes proposed.

The idea of cyclical use of consumption taxes has one very important residue, however; depression can be mitigated by getting rid of consumption taxes and intensified by creating new ones. The epidemic of sales and excise taxes in 1932I935 probably had serious adverse effects on business activity, not to mention its effects on the fairness of the distribution of tax burdens. The next time we suffer the misfortune of a major depression, we should make it the occasion for a concerted move against indirect taxes.

\section{III}

Since consumption taxes are in their administrative nature taxes which apply by special prescription to individual commodities, ${ }^{6}$ their natural field of usefulness is where differential treatment of commodities is warranted. The nature of this field was indicated in the introduction to this paper; but it needs futher examination.

Applying a tax to a particular consumption good (or removing such a tax) has two types of effects to be watched:

(I) It discourages (or encourages) use of the commodity by its previous buyers, reducing consumption volume.

(2) It reduces (or raises) the incomes which arise from the production of the commodity.

Sometimes one of these effects is to be desired and the other is to be regarded as an unfortunate by-product; sometimes both are desired.

An example of emphasis on the effect on consumption is liquor taxation. A

5 The argument for this position, in a context of inflation dangers arising from defense, is set forth briefly in the writer's pamphlet, Economic Policy for Rearmament (University of Chicago Press, Nov. I940) $22-27$, and in more detail in the forthcoming volume cited supra note *.

-Even sales taxes in practice must proceed by enumeration of things taxable. 
good deal of sentiment in the country favors limitation of liquor consumption; and taxation is welcomed largely on this ground. But the growth of the industry since Repeal has been so rapid that nobody has been much concerned about restricting the income of those connected with it. Vested interests in such income have not been recognized, and revenue and sumptuary considerations have ruled the roost.

At the other exteme is the problem of taxing increases in house and apartment rents which may result from housing scarcities under the defense program. Such taxation could be justified as a sort of excess profits tax, catching windfalls to landlords who merely happen to be fortunately placed. This justification would be purely on income grounds; the very reason for the windfall is that the supply of housing cannot quickly respond to higher rents, so that consumption, i. e. use of housing, would not be affected one way or the other.

The problems of defense also offer a convenient example of an intermediate case in which both consumption and income distribution considerations point the same way. Before defense develops much beyond the present stage, it is likely to require resources now used for automobile production; private purchases of new cars must therefore be restricted. If the number sold is reduced, higher prices can be charged. But there is no special reason why automobile manufacturers and dealers should be allowed to pocket the increase. Levying a substantial excise on new cars is likely to commend itself as a system for curtailing purchases by raising prices without unjustly enriching the sellers.

Aside from political and administrative considerations, it will be noticed, necessary restrictions of consumption could be taken care of by rationing, and prevention of windfalls in such situations by price-fixing. The combination of a higher price to consumers and an excise tax upon producers is a make-shift substitute which is plainly inferior to ideal and costless rationing and price-fixing. But it is not necessarily or even probably inferior to actually practicable rationing and price-fixing. The controls which would be necessary to take care merely of liquor, housing and automobiles would absorb a large part of the administrative resources of government, and even so would have to act either by crude rules giving very unfair allocations or with a degree of discretionary authority which would be highly dangerous. The fact that taxation can restrict consumption and catch windfalls without creating a necessity for planning the consumption of every household makes it possible to save bother and to avoid moving too far toward a government of men. In a democracy, rationing and price-fixing must remain emergency devices for limited application; and working substitutes have a high value.

Cases do arise where consumption and income effects conflict. At the present time, for example, tobacco is considered by most of us a very harmless enjoyment; and a reduction of cigarette taxes and prices to permit more consumption would be very welcome to smokers, especially in the lower income brackets. But the cigarette taxes have largely embedded themselves in the values of factories and lands 
used for tobacco production. To repeal them would give windfalls to the interests which now own this property. Cigarette taxes are thus covered in part by the traditional rule that "an old tax is a good tax," a rule which applies, of course, only to taxes affecting values of durable goods.

Fortunately, discriminatory income effects among producer groups resulting from changes in consumption taxes can be expected to iron themselves out in a few years, if they do not take hold on land values or on very specialized human skills. For moderate long-range adjustments aimed to give fair assessments of benefits from government services or to bring home social costs to nuisance-mongers, as by taxing use of soft coal without smoke arresters, such income effects may legitimately be disregarded. They are important chiefly for sudden and large adjustments such as are likely to be involved in the defense program.

Down to this point, only the regulatory aspect of consumption taxes has been considered, to the exclusion of revenue and collection costs. This exclusion, although immediately dictated by the scope suggested for this paper, conforms, the writer feels very strongly, to the basic principles of public policy on which taxation should rest. The closing paragraphs will be devoted to arguing the proposition that revenue and collection cost should be given only secondary weight in considering consumption taxes. ${ }^{\top}$

If revenue from these taxes were essential to the functioning of government, their revenue aspect would of course be central. But while this has been true in the past, it is not true at present either for our Federal Government or for any except the most completely rural state governments. The income tax is well developed in the federal system and has proved its adaptability to the uses of state governments where the states are fairly industrialized and urbanized. There is an old and wellfounded rule in economics to the effect that any revenue that could be raised by indirect taxes, can be raised more equitably by direct taxes on incomes and inheritances; the only first-order corrections to this rule are for ill effects which can be obviated by permitting averaging of tax liability over a few years and by proper interpretation of taxes to the public.

The ease of collection of neatly designed indirect taxes is a standing temptation to the legislator. But such taxes are no longer so "painless" as they used to be; gasoline taxes, sales taxes, tobacco taxes, and liquor taxes in particular, are brought forcefully to the attention of the consumer. This development should make it possible to exclude the use of consumption taxes as sources of general revenue. Needless to say, if such taxes are used where regulatory considerations call for them, the total revenue they produce will be substantial, though probably a good deal less than at present. But the rule of policy should be to regard revenue as the by-product and regulation as the main product in looking at all indirect taxes, relying for revenue upon income taxes.

\footnotetext{
'Contrast the views of Pierce, The Place of Constmers' Excises in the Tax System, supra this issuc.
} 